\title{
Evaluation Study Effect of Allowances and Job Creativity-The Performance of the Teacher in Secondary Vocational School Province of East Nusa Tenggara
}

\author{
I Made Parsa ${ }^{1}$ \\ ${ }^{1}$ University of Nusa Cendana, Kupang, East Nusa Tenggara, Indonesia \\ Correspondence: I Made Parsa, University of Nusa Cendana, Kupang, East Nusa Tenggara, Indonesia. E-mail: \\ md_parsa@yahoo.co.id
}

Received: February 28, 2017

Accepted: March 30, $2017 \quad$ Online Published: July 29, 2017

doi:10.5539/ies.v10n8p96

URL: https://doi.org/10.5539/ies.v10n8p96

\begin{abstract}
This research aims to know the influence of the allowances and the creativity of work on the performance of Secondary Vocational School teacher (SMK) in the Province of East Nusa Tenggara (Province NTT). Implementation of the survey method, i.e. to know the obvious problems with the picture of samples in field. The sample selected by random sampling technique of 4 County and 1 City in the Province of East Nusa Tenggara (Province NTT). The instruments used in this study is a questionnaire about: benefits, Working and performance and teacher creativity, who each totaled 30 items and 25 reserved. The obtained data were analyzed using path analysis.

The study found the following results: 1). Evaluation of the Allowances received by SMK teachers in NTT province did not give a positive direct effect on teacher performance, this is shown from the correlation coefficient between the allowance received by the teacher and the teacher's performance of -0.013 and the path coefficient of -0.08 . This can be interpreted that the high performance of a vocational school teacher in NTT Province is not influenced by the size of the allowance received by the teacher, 2). The evaluation of creativity gives a positive direct effect on the performance of SMK teachers in NTT Province, this is shown from the correlation coefficient between work creativity with teacher performance of 0.390 and the path coefficient of 0.403. This means that the higher the creativity of work the higher the performance, and conversely the lower the creativity of work, the lower the performance, and 3). Allowances received by SMK teachers in NTT Province give positive indirect effect on teacher performance through work creativity, this is shown from correlation coefficient between allowance received by teacher with teacher performance equal to -0.013 and path coefficient equal to -0.08 and correlation coefficient Between creativity of work with teacher performance equal to 0.390 and path coefficient 0.403 . The coefficient of combined path (indirectly) is 0.067 ; Meaning the higher the allowance received by the teacher indirectly through the creativity of the work the higher the performance of the teacher.

The research concluded that the allowances do not affect work directly against the performance of teachers. Affect the work will support the work of teachers' creativity that would have an impact on performance, The teacher SMK in Province NTT. Therefore allowances work gives an indirect influence on performance through increased teacher creativity works.
\end{abstract}

Keywords: allowances, a work of creativity, performance, teachers SMK

\section{Introduction}

The Government through the Department of education, youth and sports play an important role in the efforts of the national education quality improvement. Quality improvement in service conducted covering various aspects, good planning, implementation, enhancement of human resources, and infrastructure evaluation and quality improvement in the Ministry of education carried out by schools in Indonesia against the customer as users of educational services, which include: students, parents of students and the surrounding communities that are directly or indirectly related with the world of education.

To support the teaching and learning process, so a teacher should possess and apply a particular strategy so that students can learn effectively. This could be done in a variety of forms, for example the management of teaching. 
The management did an awful lot of manifold, say longer study time management. It can be said that learning something in the time-time of day certainly was not effective anymore, so to think about how to arrange the schedule so that lessons can be obtained the optimal schedule and can be received by students.

Currently, for example, allegedly the failure of learning process in school due to several factors including: (1) the allowance which belonged to the teacher who influenced factors such as: the descent of the objective conditions of teachers (read: teacher background); the burden of tasks; the method; and approaches that are used by teachers when teaching, (2) the interest of teachers and students on certain subjects, (3) include source materials used by teachers of mathematics.

The teacher is one of the determinants of the quality of educational outcomes. The success of organizing education are determined by the extent to which teachers ' readiness in preparing his protégé through the teaching-learning activity participants. The strategic position of teachers to improve the quality of educational outcomes are strongly influenced by professional teaching ability and the level of their well-being.

On the other hand the role and function of the teachers at the school also became one of the keys to the success of student learning on a specific field of study. An expert of education rate, teachers at the Elementary School level education, junior high, high school and Vocational School are mostly just carry out the task of transferring the science, rather than how to educate students, the demands of the profession of a teacher. Just think of the teachers how they can membelajarkan students and just think how science could be transferred as much as possible on their students. Professional teachers should be able to give you an understanding of the material field of study on the student in accordance with the maturity of students, it is one aspect of teaching assignments and other aspects related to educating students. A good teacher must understand the development of learners, mastering the process of learning and strive to develop professional skills.

As an educator, teachers are required to have a legality, competence and mastery of the material properly. In addition, the existence of a good interaction with students can support the success of the learning process. Innovation in learning will give new shades for students and will can lead to Creativity in learning and will eliminate the oversaturated in learning. Often times innovation efforts in relation to enable students, still not seem impacted activities in mathematics education. There are teachers who think that students active when look in troubleshooting and "problem" was not clear to teachers itself.; There are also other teachers assume the child must think for themselves. For it cannot be helped or guided (Dahar, 2011).

Teacher's competence is actually not in spite of it's own teacher background, good background in education, economically, the status of the environment and so on. The teacher is considered competent if he has at least a relevant Undergraduate qualification with majors in which he teaches. With such a policy, meaning that teachers are required to develop the competence of himself by the way back there to achieve a Bachelor's degree. But ironically, when teachers are required to develop competencies in order to improve the quality of the educational process, the Government has thus increasingly ignores the educational process itself. This is evident with the implementing rules of the budget hasn't been 20 for education (beyond the paycheck) and still lack of appreciation in the form of compensation to teachers.

In some areas, there are still many teachers found that teaching as an "unsung hero" and a social worker, who ended up really bad luck. This is evident by the lack of salaries of teachers in schools. Government as a determinant of policy not yet appreciate teachers as a profession that provides a lot of contribution to the education and development of Indonesia. Teachers as a profession which actually produce the leaders of Nations, other professions such as doctors, lawyers, and others, thus considered as 2 nd class citizens are considered one eye.

Low salaries granted to teachers of course unable to fullfill the needs of teachers on a daily basis, especially for teachers who have married and had children who entered school age. So it's not surprising that these teachers ultimately chose hold guidance-guidance study which proved to provide greater income than in school. In the long run this is a form of irregularities committed by teachers against the process of education, where teachers must complete the actual material in teaching at the school.

This further resulted in injustice as bad the quality of the learning process in Indonesia, which is characterized by declining creativity of teachers teaching in the classroom, teacher competence because of declining never honed and updated, as well as a decrease in the performance of the teacher in the learning process of maths at school. As a guide in this research, the author formulates the problem as follows:

a) The direct effect of the allowances received by teachers on teacher performance.

b) Direct influence between work creativity on teacher performance. 
c) Indirect influence between allowances received by teachers on teacher performance through work creativity.

\section{Review of the Literature}

\subsection{Teacher Performance}

Performance is the translation of the term United Kingdom, performance which means work achievement, execution of work, achievement of the work, or the result of performance works (LAN, 2012). Meanwhile Bernardin Russel (in Faustino Cardoso Gomes, 2010) States that the performance was: "... the record of outcomes produced on a specified job function or activity during a time period of spesified." In other words, the performance is to record learning outcomes resulting from the functioning of a particular job or activity for a period of time.

Later, Simamora (2014) looks at the performance as: "level against which employees achieve certain requirements."

Understanding performance or performance according to The Seribner Bantam English Dictionary - United States and Canada in 2007 (in Suyadi, 2009), "performance or performance is the result of work that can be accomplished by a person or group of people within an organization, in accordance with the authority and responsibilities of each in order to achieve the goals the organization concerned efforts to legally, does not violate the law and in accordance with the norms and ethics."

Kane (2010) defines performance as "learning outcomes the hard work of the Organization in realizing the strategic goals defined the organization." While A. A. Anwar Prabu Mangkunegara said that performance was the result of the quality and quantity of work that is a person in the exercise of his duties in accordance with the responsibilities given to him. While Wahjosumidjo (2014) says performance is the result of the interactions that occur between perception and Creativity on one's self can be seen in the form of the person's behavior.

Waldman (2014); the performance is a combination of behavior with the accomplishment of what was expected and the choices or the terms of an existing task in each individual in the organization. Whereas according to the Mangkunegara (2011); performance can be defined as a result of the quality and quantity of work which can be reached by a person in performing the duties of employees in accordance with the responsibilities given to him. (H. Friend Koesmono, Journal of Management).

Cascio (2013) said that the performance of the employee's performance of the duties of the tuganya that has been set. Soeprihantono (2008); said that the performance was the result of work of an employee during a specific pereode in comparison with the various possibilities, for example standard, targetsasrancriteria have been determined in advance and agreed upon together. (H. Friend Koesmono, Journal Of Management).

Performance measurement should reflect the past, not the goal to strive for, but rather a means to tap into more productive future. In order to achieve its potential, performance assessment is not enough to just do it, but employees should act according to his judgment of it. Usually the tops have a responsibility to communicate the results of his assessment to his subordinates and to help subordinates improve in the future. Otherwise subordinates usually has the responsibility of looking for honest feedback and use it to improve its performance.

Performance standards of each people have differences according to the type of work, organization or profession. Performance standards refer to the objectives of the Organization are described in a functional tasks. Government employees will be different standards by the standards of industrial workers, because each has a different tugaspekerjaan specification. As a graduate of This performance with the performance of a High School graduate could not equal, depends on the level of ability that belongs to each of the graduates.

The legislation of the Republic of Indonesia No. 14 of 2005 about the teachers and professors article 1 States: "teachers are professional educators with the main task of educating, teaching, guiding, directing, train, assess, and evaluate learners early childhood education on the formal education, elementary education, and secondary education."

Oemar Malik in the book the psychology of learning and teaching is teacher tenure say selected based on principles vokasional. Further he said that teachers play a role to help students change the behavior of the Act in accordance with the desired direction, i.e. the processes (change behavior) and criteria (the preferred direction specifically) are formulated in the educational purposes.

Next Oemar Malik said, "the task of the teacher is berinterelasi with their students by creating conditions and materials, by manipulating the situation that allows students to change behaviour in accordance with the wishes of it as has been predicted before. Because learning situations that are different, therein lies the importance of the 
teacher was active as an ongoing basis, namely the inventors find procedures deems reliable. The decisions of educators about the methods, materials and curriculum are still basically procedure as a hypothesis needs to be tested continually by finding a level where it would happen in actual behaviour change. " (Malik, 2012).

Teacher, digugu and emulate. An idiom which personifies how great the profession of a teacher. It is very fitting attached on the profession of a teacher, remembers the teacher is actually an educator that provides examples and educational services for children of his protégé. A pupil must follow all the commands and examples given by his teacher, because students see that the teacher is a figure who deserves to be imitated, either through attitudes, words and deeds.

Republic of Indonesia law No. 20 of 2003 on the national education system in article 39 paragraph (2) States: "Educators are professionals who are in charge of planning and implementing the process of learning, assessing learning outcomes, conduct supervision and training, as well as conducting research and devotion to society, especially for educators at College."

Based on the study of the above theory, it can be concluded that the performance of the teachers in this study is the result of work achieved by someone whose profession as educators as well as have a legality as a teacher in the field of study of mathematics. Divided in two dimensions, namely the teaching dimension and dimension the educator.

\subsection{Creativity}

Creativity comes from the latin word Movere which means encouragement or direct. Creativity question how do I steer the power and potential of subordinate, to work together productively so that managed to reach or realise who has been determined.

Creativity is terminating causes, from supporting human behavior, that want to work actively and enthusiastically has weathered the optimal results. An organization is not just hope their employees are capable, qualified and skilled, but also the most important employees willing to work actively to achieve optimal working results. The abilities and skills of employees are meaningless for the company or institution if they don't want to work with enterprising. According to research results Veithzal Rivai (2012) in Jabodetabek, human resources who have high creativity, can improve management work in the company.

Based on its shape, creativity is distinguished into two, namely:

\section{a. The intrinsic Creativity}

Creativity is the impetus for the work deriving from the employees as individuals, i.e. either an awareness about the importance of benefits or whatever he does.

\section{b. Creativity Extrinsic}

This is the driving force of creativity work sourced from outside yourself employees as individuals, namely in the form of a condition that requires that the individual perceived work to its full potential, for example, highly dedicated, Honorable position or have a great power, praise, punishment and others.

From the above description, it can be concluded that the definition of creativity in this study was an impetus from within and from outside the self employee to work on a task with an as well as possible out of necessity, based on the terms of reference of success. Or in other words, attempts, encouragement and willingness of employees that directs their behaviour to perform the duties and responsibilities properly measured through indicators: earn rewards, the establishment of cooperation, respect, self-actualization and fulfillment in your work environment.

\subsection{Allowances to Teachers}

According to etymological dictionary Review of Indonesian Language, alimony is punitive damages; finished debts by providing goods for the loan; search for fulfillment in the field to obtain the balance of disappointment in other fields; rewards in the form of money or not money (natura), which is given to the employee within a company or organization.

While salary is the wage paid work within the time fixed; workers received retribution in the form of money based on a certain time. Wage is money and so forth paid as an avenger of services or as the power is removed from the blood to grind.

From the above definition can be stretched the notion that someone who has been doing the job duties and responsibilities be eligible to earn a wage, salary or allowances for all his achievements, and the magnitude of the (supposed) in accordance with the work that he did. 
According to Schuler and Jackson (2009), and Siagian (2010) in principle reward can be distinguished into two, namely extrinsic rewards and intrinsic rewards. The intrinsic rewards that employees received in return for himself. Usually this is the positive value in return or complacency employee against itself because it has completed a task for him is quite challenging. Job enrichment techniques, such as granting role in decision-making, greater responsibility, freedom and greater leeway to work with aim to improve employee self-esteem, intrinsically a reward for employees (Ninuk, 2012).

Extrinsic rewards include compensation direct, indirect compensation and reward instead of money. Included in direct compensation, among others, is base salary, overtime, wage payment incentives, allowances, bonuses; Whereas indirect compensation includes, among others, social security, insurance, retirement, severance, sabbatical work, training and leisure. The reward is not money is the employee received satisfaction from the work itself or from the psychological environment danatau phisik where employees work. Including rewards instead of money such as a sense of security, or a comfortable working environment, personal development, career flexibility, increase revenue opportunities, status symbol, praise and recognition.

SMK Teacher prosperity Allowance policy while it can only be enjoyed by teachers in the city of Province NTT, in particular civil servant. Additional income enjoyed by teachers started since year 2008 which is 250.000 IRD; then up to $500.000 \mathrm{IRD}$, in 2010. The next component in 2010 earnings increased teacher received, so that not only the prosperity but there are also components of the education support and Special Allowances (for teachers and medical personnel).

Basis of calculation of allowances used to obtain fair alimony payment system, and makes the company attractive, able to survive and be able to access their employees 'creativity and can do cost savings. According to Gomez-Mejia, et al. (2013), the basis of calculation of compensation can be distinguished into two categories, namely, using the approach of employment or terms (job-based approaches) and use the approach of skill (skill-based approaches). Approach to a job or position assumes that the job can be done by the person who paid for a particular position, whereas the skills approach assumes that the employee was not paid because the Office which he carried, but rather in its ability to accomplish the task.

From the explanation above it can be concluded that is the benefits of teachers in this study was the wages or remuneration received by regular teachers every month because teachers have been doing their job, which is to teach and educate their students. Plus award other forms that cannot be expressed in the form of the material.

1) The direct effect of Allowances received by the teacher against teacher Performance

Allowance expressed as an award received by a person who has given the effort, time and mind to work and give my best for the organization. Form of allowances can usually be either material or non material and. A person who is given a decent allowance will be able to meet every need, so that they will not neglect doing his duty, because looking for moonlighting.

Performance, such as already disclosed before a performance. Someone who has good performance are those who are able to work out what the duties and responsibilities. A person who performs well will normally be offset by improvements in terms of allowances and awards given to him.

From the explanation above, supposedly there is a direct positive influence amongst the allowances received by a teacher against a teacher's performance. That is, the higher the alimony received by teachers and the higher performance of the teachers, instead the lower allowances received by teachers and the lower the performance of teachers.

2) Direct influence Creativity Work against Performance teacher

Creativity is its driving force and has always been the reason or the underlying motive of someone doing something. Usually someone with creativity because they expect something better in the future or in other words there is a ideal of their movement. People who have a high creativity usually will do everything properly and earnestly.

Performance is expressed in the form of the work or the performance of a person. A person is said to have good performance if they at least do what the duties and responsibilities. However, it would be better if they were doing a lot better than just hit the target desired by the Organization of work.

From the explanation above, supposedly there is a direct positive influence amongst the working teacher creativity against the performance of teachers. It means more work and creativity will be the better its performance and instead the less creativity work then it will be the lower the performance.

3) The influence of indirect Allowances received the teacher of the teacher's Performance through Creativity 
Works

Allowances are awards received by a person who has given the effort, time and mind to work and give my best for the organization. Form of allowances can usually be either material or non material and. A person who is given a decent allowance will be able to meet every need, so that they will not neglect doing his duty, because looking for moonlighting.

Creativity is its driving force and has always been the reason or the underlying motive of someone doing something. Usually someone with creativity because they expect something better in the future or in other words there is a ideal of their movement. People who have a high creativity usually will do everything properly and earnestly. The trend is happening now, someone will be more elegant creativity if they get enough allowances to meet the needs of his life.

Performance, such as already disclosed before a performance. Someone who has good performance are those who are able to work out what the duties and responsibilities. A person who performs well will normally be offset by improvements in terms of allowances and awards given to him.

To that end, there are the indirect influence of the allegedly positive between allowances received by a teacher against teacher performance through creativity work teacher. From the explanation above, the authors tried to submit some hypothesis as follows:

a) There is a direct positive effect between the Allowances that teachers receive on teacher performance.

b) There is a direct positive effect between work creativity on teacher performance.

c) There is an indirectly positive influence between the Allowances that teachers receive on teacher performance through work creativity.

\section{Research Methodology}

The research was held in the city of Province NTT, the Secondary Vocational Schools is Scrutinized (SMK). The sampling technique used is to use the cluster area combined with random sampling, where taken at random from the SMK Division 4 County and 1 City in the Province NTT. The number of samples taken as many as 150 people to Vocational teacher, where the research was carried out for 6 months.

The analysis of the data used is by using path analysis, i.e. to see the direct and indirect influences between variables was examined. To give you a clear picture, then it can be described as follows: design research

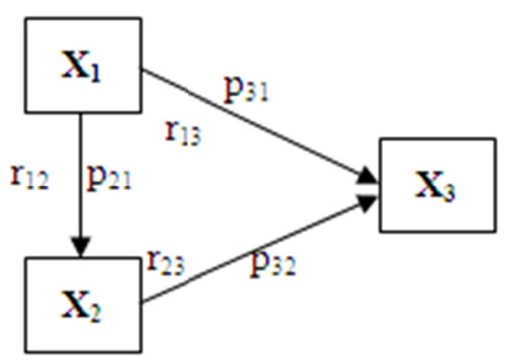

Description:

$\mathrm{X}_{1}$ Allowances received by teachers

$\mathrm{X}_{2}$ A work of creativity of teachers

$\mathrm{X}_{3}$ Performance teachers

Research Results

Test Requirements Analysis

As a condition to continue the analysis of the data, it needs to be done test result data, where average as follows: 
Table 1. Data Normality Test SPSS Program "One-Sample Kolmogorov-Smirnov Test"

a. Test distribution is Normal.

\begin{tabular}{llccc}
\hline & & Allowances & Creativity & Activity \\
\hline $\mathrm{N}$ & & 149 & 150 & 150 \\
Normal Parameters ab & Mean & 83.5867 & 97.1327 & 153.2522 \\
& Std. Deviation & 17.73422 & 10.31332 & 11.74140 \\
Most Extreme & Absolute & .130 & .123 & .108 \\
Differences & Positive & .056 & .123 & .047 \\
& Negative & -.130 & -.081 & -.108 \\
Kolmogorov-Smirnov Z & & 1.957 & 1.847 & 1.629 \\
Asymp. Sig. (2-tailed) & & .001 & .002 & .010 \\
\hline
\end{tabular}

b. Calculated from data.

From the table above that the results obtained the value of sig allowances 0.001 ; the value of GIS for creativity 0.002; and the value of sig to 0.010 performance. This result is obtained from the conclusion that the value of the sig for all the variables below 0.05 ; so it can be concluded that no normal Gaussian data, so that other assumptions are not necessary and the process of data analysis is carried out using a non-parametric statistics.

\section{Test of Hypothesis}

The process of hypothesis testing is done using path analysis, namely finding the coefficient between variables that influence one towards the other variable, either directly or indirectly. The calculation process is carried out with the help of the program SPSS 16.0 and also with the manual calculation. The calculation of the correlation coefficient will be obtained results and path coefficient for each variable.

Given the data is not normal Gaussian, then the step data analysis that is done is to use a non-parametric statistics, so in this case to calculate the correlation between the variables was done using correlation Kendal's Tau. Where using computer programs obtained the following results:

Table 2. Analysis of the relationship of the program SPSS "Correlations"

\begin{tabular}{|c|c|c|c|c|c|}
\hline & & & Allowances & Creativity & Activity \\
\hline \multirow{9}{*}{ Kendall's tau_b } & & Corelation Coefficient & 1.000 & $.167 * *$ & -.013 \\
\hline & Allowances & Sig. (2- tailed) & - & .000 & .781 \\
\hline & & $\mathrm{N}$ & 149 & 149 & 149 \\
\hline & & Corelation Coefficient & $.167 * *$ & 1.000 & $.390 * *$ \\
\hline & Creativity & Sig. (2- tailed) & .000 & - & .000 \\
\hline & & $\mathrm{N}$ & 149 & 150 & 150 \\
\hline & & Corelation Coefficient & -.013 & $.390 * *$ & 1.000 \\
\hline & Performance & Sig. (2- tailed) & .781 & .000 & - \\
\hline & & $\mathrm{N}$ & 149 & 150 & 150 \\
\hline
\end{tabular}

** Correlation is significant at the 0.01 level (2-tailed).

Or it can also be described as a relationship such as the following:

Table 3. Simple correlation relationship

\begin{tabular}{lccc}
\hline Correlation & $\mathrm{X}_{1}$ & $\mathrm{X}_{2}$ & $\mathrm{X}_{3}$ \\
\hline $\mathrm{X}_{1}$ & 1 & 0.167 & -0.013 \\
$\mathrm{X}_{2}$ & 0.167 & 1 & 0.390 \\
$\mathrm{X}_{3}$ & -0.013 & 0.390 & 1 \\
\hline
\end{tabular}

Equation for finding the coefficients as follows:

$\mathrm{r}_{12}=\mathrm{P}_{21}$

$\mathrm{r}_{13}=\mathrm{P}_{31}+\mathrm{P}_{32} \mathrm{r}_{21}$ 
$\mathrm{r}_{23}=\mathrm{P}_{31} \mathrm{r}_{12}+\mathrm{P}_{32}$

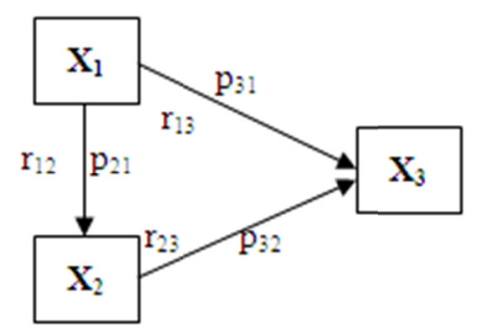

So the equation is obtained as follows:

$0.167=\mathrm{P}_{21}$

$-0.013=\mathrm{P}_{31}+0.167 \mathrm{P}_{32}$

$0.390=0.167 \mathrm{P}_{31}+\mathrm{P}_{32}$

Furthermore by using substitution or elimination or matrix can be specified with the value of the coefficient effects, as follows (in this case the author is using elimination and substitution):

$\mathrm{P}_{21}=0.167$

$\mathrm{P}_{31}=\frac{\left|\begin{array}{cc}-0.013 & 0.167 \\ 0.390 & 1\end{array}\right|}{\left|\begin{array}{cc}1 & 0.167 \\ 0.167 & 1\end{array}\right|}=\frac{-0.013-0.06513}{1-0.027889}=\frac{-0.07813}{0.972111}=-0.08$

$\mathrm{P}_{32}=\frac{\left|\begin{array}{cc}1 & -0.013 \\ 0.167 & 0.390\end{array}\right|}{\left|\begin{array}{cc}1 & 0.167 \\ 0.167 & 1\end{array}\right|}=\frac{0.390+0.002171}{1-0.027889}=\frac{0.392171}{0.972111}=0.403$

Calculation of the results obtained the following results:

$\mathrm{P}_{21}=0.167$

$\mathrm{P}_{31}=-0.08$

$\mathrm{P}_{32}=0.403$

The overall results of the above calculation line diagram is obtained as follows:

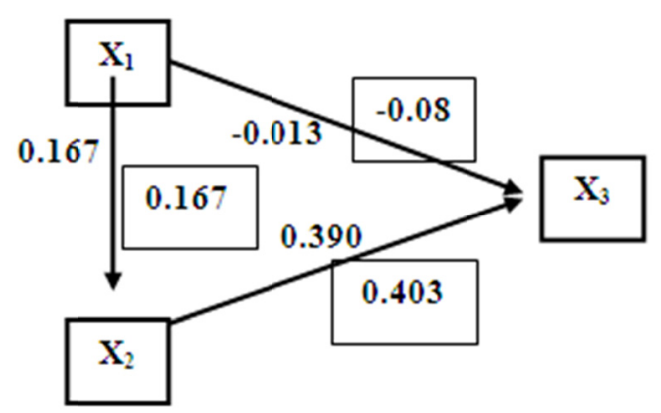

\section{Hypothesis 1}

$\mathrm{H}_{0}: \quad \mathrm{P}_{31} \leq 0 \quad \rightarrow \quad$ There is no direct positive influence amongst the allowances received by the teacher against teacher performance

$\mathrm{H}_{1}: \mathrm{P}_{31}>0 \quad \rightarrow \quad$ There is a direct positive influence amongst the allowances received by the teacher against teacher performance. 
The test criteria:

Accept reject $\mathrm{H}_{0}$ and $\mathrm{H}_{1}$ if $\mathrm{P}_{31}<0.05$

Reject $\mathrm{H}_{0}$ and $\mathrm{H}_{1}$ if received $\mathrm{P}_{31}>0.05$

From the diagram it looks that the coefficient of correlation between $\mathrm{X}_{1}$ and $\mathrm{X}_{3}$ is the coefficient and the influence of $-0.013\left(\mathrm{P}_{31}\right)$ of- 0.08 ; so:

Accept reject $\mathrm{H}_{0}$ and $\mathrm{H}_{1}$ because $\mathrm{P}_{31}<0.05$.

Or in other words the line from $\mathrm{X}_{1}$ to $\mathrm{X}_{3}$ non-significant.

So concluded the data do not support the hypothesis, or in other words there is no positive influence significant directly between the allowances received by a teacher against a teacher performance SMK in Province NTT.

\section{Test Hypothesis 2}

$\mathrm{H}_{0}: \quad \mathrm{P}_{32} \leq 0 \quad \rightarrow$ No direct positive influence creativity work against performance teacher.

$\mathrm{H}_{1}: \mathrm{P}_{32}>0 \rightarrow$ There are positive influences directly between a work of creativity of teacher performance.

The test criteria:

Accept reject $\mathrm{H}_{0}$ and $\mathrm{H}_{1}$ if $\mathrm{P}_{32}<0.05$

Reject $\mathrm{H}_{0}$ and $\mathrm{H}_{1}$ if received $\mathrm{P}_{32}>0.05$

From the diagram it looks that the coefficient of correlation between $\mathrm{X}_{2}$ and $\mathrm{X}_{3}$ is the coefficient and the influence of $-0.390\left(\mathrm{P}_{32}\right)$ of- 0.403 ; so:

Accept reject $\mathrm{H}_{0}$ and $\mathrm{H}_{1}$ because $\mathrm{P}_{32}>0,05$.

Or in other words the line from $\mathrm{X}_{2}$ ke $\mathrm{X}_{3}$ significant.

So concluded the data support the hypothesis, or in other words, there is a positive influence directly a significant work of teacher creativity between the performance of a teacher in SMK Province NTT.

\section{Test Hypothesis 3}

$\mathrm{H}_{0} \quad: \mathrm{P}_{21} \cdot \mathrm{P}_{32} \leq 0 \quad \rightarrow$ There is no positive influence indirectly received allowances between teachers of teacher performance through creativity works

$\mathrm{H}_{1} \quad: \mathrm{P}_{21} \cdot \mathrm{P}_{32}>0 \quad \rightarrow$ There is an indirect positive influence between the allowances that teachers receive on teacher performance through work creativity

The test criteria:

Accept reject $\mathrm{H}_{0}$ and $\mathrm{H}_{1}$ if $\mathrm{P}_{21} . \mathrm{P}_{32}<0.05$

Reject $\mathrm{H}_{0}$ and $\mathrm{H}_{1}$ if received $\mathrm{P}_{21} . \mathrm{P}_{32}>0.05$

From the diagram above to see that the coefficient of correlation between $X_{1}$ and $X_{2}$ is the coefficient and the influence of $0.167\left(\mathrm{P}_{21}\right)$ for 0.167 ; as well as the coefficient of correlation between $\mathrm{X}_{2}$ and $\mathrm{X}_{3}$ is the coefficient and the influence of $0.390\left(\mathrm{P}_{32}\right)$ of 0.403 ; so come by indirect influence coefficients between $\mathrm{X}_{1}$ to $\mathrm{X}_{3}$ through $\mathrm{X}_{2}$

$\mathrm{P}_{21} \cdot \mathrm{P}_{32}=(0.167) \cdot(0.403)=0.067$

So:

Reject $\mathrm{H}_{0}$ and $\mathrm{H}_{1}$ because the receipt $\mathbf{P}_{\mathbf{2 1}} . \mathbf{P}_{\mathbf{3 2}}>\mathbf{0 . 0 5}$.

Or in other words the line from $\mathrm{X}_{1}$ to $\mathrm{X}_{3} \mathrm{X}_{2}$ through significant.

So concluded the data support the hypothesis, or in other words, there is a positive influence indirectly the significant between the allowances received by a teacher against a teacher performance SMK in Province NTT through the creativity of teachers work.

\section{Discussion of the Results of Research}

1) Discussion of the Results of Hypothesis 1: There Is No Direct Positive Influence amongst the Allowances Received by the Teacher against Teacher Performance

The result of the hypothesis 1 test shows that it gives non-significant results, which can be interpreted that there is no direct influence of the variable allowances received by the teacher on teacher performance variables, this is because the allowance provided by the Government is considered as acceptable acceptance of the performance 
Yag already done teacher. Allowances are a form of appreciation received by SMK teachers in both material and non-material forms that accompany the occupational profession and social status as a teacher. Allowances received by the teacher may include the provision of salaries, health facilities, insurance, educational tuition fees, and also include priority in the administration of public matters (such as ease of home loans, motor vehicle loans and so on) From the surrounding community to the performance figures performed by a teacher.

The fact of the evaluation in this study confirms that it turns out that a vocational teacher who gets more and more various Allowances and facilities in the various facilities will actually further reduce the level of work. Evaluation facts of this research need to be considered well, given the considerable provision of Allowances for teachers of SMK in NTT province has recently been enacted. Perhaps this creates a tremendous effect of surprise among teachers, those who usually work on relatively low wages, suddenly earn substantial money, so that perhaps because their needs begin to be met the teachers start lazy to do their work as an educator.

While from other evaluations are many vocational teachers who express the lack of public awards to the figure of a teacher, this is stated in the questionnaire that the contents of the lack of priority given to teachers in connection with housing and motor vehicle facilities. In addition, today's view of the people in Kupang City of NTT towards teacher figures has begun to wear off, people no longer see the teacher as a resource person and place a complaint, but become a scapegoat for the failure of their children in school.

However, if we see further that the work of SMK teachers in NTT Province is still relatively high, it should provide little insight that for teachers there is no influence between what they receive or any awards they receive on their performance. Furthermore it can be said that no matter the low appreciation given to teachers, the teachers still provide the best work in their work. While Supardi's (2009) study results on elementary school teachers in South Jakarta that the increased primary school teachers' Allowances will increase their work, to the service in learning to their students.

Evaluation of this research further confirms that the profession as a teacher is still a noble profession (hopefully forever), because regardless of compensation it turns out the teachers still work well. Because the teachers of SMK basically have a high professional competence and diverse in various disciplines of science. As a vocational teacher in addition to having the necessary competencies also in life in the general public. While for the profession of SMK teachers provide more ability to improve the excellent work in school and or outside school.

2) Discussion of the Results of Hypothesis 2: There Are Positive Influences Directly between A Work of Creativity of Teacher Performance

The results of hypothesis 2 calculation gives significant results, meaning there is a positive direct influence between work creativity on teacher performance. Actually, the evaluation of this research is a fact that can not be negotiable, because indeed in theory and facts in the field clearly proves that only people who have high creativity that can provide high performance as well.

Creativity for a teacher's performance evaluation is an extraordinary amount of extra vitamins and energy that can move many things in a person's life. There are many ways that can be done to generate teacher creativity, for example by following various seminars that burn the creativity of a person's work or can also provide some rewards if the requested target can be achieved well.

Creative teachers are teachers who can change any perception in themselves into positive perceptions. Creative SMK teachers are teachers who can do whatever is possible for some people is considered impossible. Creative teachers are teachers who can perform activities several times stronger than other teachers. In the evaluation of teachers' creativity is given meaning and meaning as a super teacher. According to research results Veithzal Rivai (2012) in Jabodetabek, human resources who have high creativity, can improve management work in the company. Kretivitas research referred to provide a very significant role for the achievement of target employment management of employees at companies in Greater Jakarta.

In the evaluation of this research, it is seen that SMK teachers' work creativity is more generated from satisfaction indicator in work environment, it gives meaning that actually for the teachers in a conducive and comfortable working environment is a small detonator that can blow up the big power inside him. Creativity supported by comfortable and safe working conditions can provide additional energy for teachers to work more focused and good at transferring their knowledge to the students they are educating.

3) Discussion of the Results of Hypothesis 3: There Is an Indirect Positive Influence between the Allowances that Teachers Receive on Teacher Performance through Work Creativity

The result of hypothesis 3 , gives result that there is indirect influence between allowance received by teacher to 
teacher performance through work creativity done by SMK teacher.

The results of the evaluation of the research above, that high work creativity will produce high performance, it has also been explained that the main element of improving teacher work creativity is satisfaction in work environment. The second thing that becomes the determinant element of teacher creativity improvement is the reward or allowance, meaning the higher the allowance received by the teacher will increase creativity. From this fact it can be stated that it turns out to increase the Allowances received by SMK teachers in NTT province although not directly improve the performance of teachers but will increase the creativity of teachers work that will ultimately improve the performance of SMK teachers. In general, the Allowances received by teachers in NTT in the form of awards and materials, can have a considerable impact on the performance improvement of teachers in NTT (Department of Education Youth and Sports NTT Province, 2010).

Allowances, as noted above, are forms of appreciation that teachers receive. The form of awards in the form of materials and non-material will usually make the teacher feel eager to move and do their duties and obligations as educators, not only educators in schools but also in the community environment. The impact indirectly by improving the creativity of teachers work will also increase the performance of teachers concerned.

\section{Conclusion}

1) Evaluation of the Allowances received by SMK teachers in NTT province did not give a positive direct effect on teacher performance, this is shown from the correlation coefficient between the allowance received by the teacher and the teacher's performance of -0.013 and the path coefficient of -0.08 . This can be interpreted that the high performance of a vocational school teacher in NTT Province is not influenced by the size of the allowance received by the teacher.

2) The evaluation of creativity gives a positive direct effect on the performance of SMK teachers in NTT Province, this is shown from the correlation coefficient between work creativity with teacher performance of 0.390 and the path coefficient of 0.403 . This means that the higher the creativity of work the higher the performance, and conversely the lower the creativity of work, the lower the performance.

3) Allowances received by SMK teachers in NTT Province give positive indirect effect on teacher performance through work creativity, this is shown from correlation coefficient between allowance received by teacher with teacher performance equal to -0.013 and path coefficient equal to -0.08 and correlation coefficient Between creativity of work with teacher performance equal to 0.390 and path coefficient 0.403 . The coefficient of combined path (indirectly) is 0.067 ; Meaning the higher the allowance received by the teacher indirectly through the creativity of the work the higher the performance of the teacher.

\section{Recommendations}

1) Vocational teachers in NTT Province as a profession must maintain its existence in facing the challenges ahead. This result clearly gives a very high appreciation for the teaching profession, where the teacher as a profession is very independent of the amount of Allowances received. Therefore, the results of this research can be used as a whip for the teachers of SMK to work better again.

2) The Government, Principals, Teachers and Education Elements in NTT Province should keep trying to improve teachers' creativity because it is evident that teacher work creativity is a key element of teacher performance. The government must be able to create various programs that can improve teachers' work creativity.

3) The government, all stakeholders of the school and the general public, should be able to improve the welfare of teachers in both material and non-material forms. The parties who have the authority to raise the salary of teachers, should be able to do so, and people who are always in touch with teachers can give more appreciation to the teachers, especially in terms of giving priority in relation to the provision of legal aid, home loan application, and so forth.

\section{References}

Badudu, J. S., \& Sutan, M. Z. (2006). Common Indonesian Language Dictionary. Jakarta: Pustaka Sinar Harapan.

Cascio. (2013). Performance Is Achievement Performed by Employees. Jakarta: PT. Erlangga.

Dahar. (2011). Personnel Management: Human Resource Management. Jakarta: Indonesia Ghalia.

Department of Education Youth and Sports NTT Province. (2010). The Provincial Teacher Performance Report NTT. Kupang: East Press 
Kane, B. (2010). Manajement System Performance. Jakarta: PT Gramedia Pustaka Main.

LAN. (2012). SPSS Statistical Parametric. Jakarta: PT Elex Media Komputindo, Gramedia Group.

Malik, O. (2012). Research Guide. Jakarta: Pustaka Publisher Feat.

Mangkunegara. (2011). Human Resource Management and Development Strategies. Jakarta: University Of IGI.

Ninuk, M. (2012). Quantitative Analysis Laboratory Module For article writing research results. Jakarta: Trisakti University.

Shuleder, R. S., \& Jackson, S. E. (2009). Personnel Management And Human Resources (2nd ed.). New York: The Publisher HRD.

Siagian. (2010). Educational Research Methods. Bandung: Alfabeta.

Simamora, H. (2014). Learning and the Factors That Affected it. Jakarta: Cipta Rimeka.

Soeprihanto. (2008). Performance Appraisal and Employee Development. Yogyakarta: BPFE.

Sudjana. (2010). Statistical Methods (6th ed.). Bandung: Tarsito.

Supardi et al. (2009). Relationship of Allowance and Achievement of Elementary School Teachers in DKI Jakarta. Jakarta: Unindra Research Results.

Suyadi, P. (2009). Office Management. Jakarta: Pt. Trigenda Publisher Of The Paper.

Veithzal, R. (2012). Creativity and Human Resource Management for the Company. Jakarta: Uhamka Research Results.

Veithzal, R. (2014). Management of Human Resources For the Company. Jakarta: Rajagrafindo Persada.

Wahjosumijo. (2014). Psychology of Education. Jakarta: PT Raja Grafindo Persada.

Waldman. (2014). Learning Achievement in Achievement of Work Achievement. Bandung: Alfabeta.

\section{Copyrights}

Copyright for this article is retained by the author(s), with first publication rights granted to the journal.

This is an open-access article distributed under the terms and conditions of the Creative Commons Attribution license (http://creativecommons.org/licenses/by/4.0/). 